\title{
An Analysis of the Need for Developing E-Module Based on Problem Based Learning Utilizing Virtual Laboratory on the Digestive System Material
}

\author{
Natalia Dwiasty Ravista ${ }^{1,}$ Sutarno $^{2, *}$ Harlita $^{3}$ \\ ${ }^{1}$ Master of Biology Education, Postgraduate School, Universitas Sebelas Maret, Indonesia \\ ${ }^{2}$ Department of Biology, Faculty of Mathematics and Natural Science, Universitas Sebelas Maret, Indonesia \\ ${ }^{3}$ Department of Biology Education, Faculty of Teacher Training and Education, Universitas Sebelas Maret, \\ Indonesia \\ *Corresponding author. Email: nnsutarno@yahoo.com.
}

\begin{abstract}
The purpose of this study was to analyze the need for the development of an e-module based on PBL with the help of a virtual laboratory on the digestive system material at Baleriwu Danga Senior High School, Flores, NTT. This research is an early stage (Research and information collecting) included in Borg and Gall's R \& D model. Data collection techniques used were documentation, interviews with biology teachers, and questionnaires for students who have studied the digestive system material. The data obtained were analyzed descriptively. The results pointed out the fact that biology lessons had not used teaching materials that could facilitate students in constructing their knowledge. The used -teaching materials were still conventional (printed), so they did not attract student's interest in learning and have not followed the latest development of science and technology. Besides that, teachers also rarely held practical activities due to limited tools and materials. Therefore, it is necessary to develop an e-module based on PBL with the help of a virtual laboratory to help students understand the concept of the digestive system independently through interesting activities. The developed e-module can be accessed through smartphones.
\end{abstract}

Keywords: E-module development, Problem- based learning, Virtual laboratory

\section{INTRODUCTION}

Science studies about oneself, the surrounding environment, as well as problems and solutions to overcome these problems [1]. Biology is a branch of science that studies living things and other aspects relating to life. Learning biology is not just knowing the form of concepts, facts, or principles, but also the process of how to find and construct one's knowledge. This is in line with the principle of constructivist learning described by Suparno in [2], learning is not merely an activity to gather facts but aimed to develop thoughts by making new meanings.

The material of the digestive system is a fairly complex biological matter, starting from the constituent organs, functions, processes that occur in it, and abnormalities in the digestive system. Therefore, there is a need for a strategy that can teach the material on the digestive system. Many things can be done by the teacher to teach the material on the digestive system, one of which is by using a module. In general, the modules used in schools are still conventional (printed). The rapid development of science and technology requires teachers to utilize and improve Information and Communications Technology (ICT) competencies in learning activities. This led to a transition from a conventional module (print) to an e-module (electronic version of the module) which can be accessed on computers or smartphones. However, an e-module that can run on smartphones will be more effective. Smartphones are mobile devices that can be used for various multimedia such as computers, but smartphones have higher mobility [3] and are smaller in size that makes them more practical to carry and use at the desired time. The Directorate of Senior High School in [4] explains that an e-module is a form of presenting material that is systematically arranged to facilitate students to learn independently. Each learning activity packaged in an e-module is linked with a link as navigation which 
aims to make it easier for teachers and students to use. The e-module should also be equipped with animations, videos, images, and audio to provide a learning experience and can attract student interest and motivation in learning.

E-module can be used more easily if it is integrated with a learning model. E-module that are integrated with the learning model will facilitate students with various interesting activities that correspond to the learning model syntax which aims to makes students more active in learning. One of the learning models that can be integrated into an e-module is Problem Based Learning (PBL). PBL is a pedagogical approach that allows students to learn and be actively involved with meaningful problems, where students are allowed to solve problems collaboratively and practice independent study habits through practice and reflection [5]. PBL is an instructional method that aims to prepare students to face the real world that requires them to solve problems as the main format of teaching [6]. PBL consists of five syntaxes, namely; 1) orientation of problems to students, 2) organizing students to learn, 3) guiding individual and group investigations, 5) analyzing and evaluating the problem-solving process [7]. The most important thing in PBL is how students carry out investigations to find solutions to problems that have been previously identified [7]. Investigations can be facilitated through group discussions with the help of books, journals, or other sources to find concepts related to the problem to be solved [8]. Besides that, investigations can also be facilitated by experimental methods. Experiments choose should be supported by adequate laboratory facilities including tools and materials. However, not all schools have adequate laboratory facilities, so that the material that should be studied by conducting experiments is replaced with lectures or group discussions. In the digestive system material, there are sub materials that must be studied by conducting experiments, namely; in the sub-material of food substances, where an experiment is needed to test the nutritional content of the food.

Along with the development of science and technology, an innovation that can overcome the limitations of laboratory facilities had been created and it is called a virtual laboratory. A Virtual laboratory is a laboratory facility that includes tools and materials in the form of software-based interactive multimedia, which can be operated via a computer or smartphone and functions to simulate learning activities in the laboratory as if the user were in a real laboratory [9]. The advantages of virtual laboratories are that they allow students to repeat simulations that have not been understood and experiments with materials that are too dangerous and take too long to do in a real laboratory [10], as well as providing learning experiences that can overcome individual differences, where individuals can use the time according to their respective needs in the use of these simulations [11]. Besides that, a virtual laboratory can be used at the desired time and place [12]. Thus, this study aims to analyze the need for the development of an e-module based on PBL with the help of a virtual laboratory on the digestive system material.

\section{METHODS}

This research is part of Borg and Gall's R\&D model which consists of 10 stages, namely: 1) Research and information collecting, 2) Planning, 3) Development preliminary form of product, 4) Premilinary Field Testing, 5) Main Product Revision, 6) Main Field Testing, 7) Operational Product Revision, 8) Operational Field Testing, 9) Final Product Revision, 10) Dissemination and Implementation. This research is still limited to the research and information collecting stage, which includes analysis of needs in developing PBL-based emodules with the help of a virtual laboratory.

This research is a qualitative descriptive study. The subjects that were used biology teachers and 42 students of class XII science at Baleriwu Danga Senior High School, Flores, NTT who had studied the food digestive system material. The data collection techniques include, 1) Mapping documentation of National Examination results according to BSNP for the last 2 years, especially students' absorption of digestive system material, 2) a student needs analysis questionnaire, 3 ) interviews with biology teachers.

\section{RESULTS}

The data obtained in this study were: 1) mapping the absorption capacity of Baleriwu Danga Senior High School students, Flores, NTT according to BSNP on the material of the digestive system for the past 2 years, 2) analysis of student needs based on the results of distributing questionnaires, 3) analysis of teacher needs to be based on the interview results.

\subsection{Data on Student Absorption Capacity Mapping According to BSNP}

Data on the mapping of the absorption capacity of Baleriwu Danga Senior High School students, Flores, NTT according to BSNP on the material of the digestive system for the last 2 years is presented in table 1 . 
Table 1. The percentage of students' absorption of the digestive system material

\begin{tabular}{|c|c|c|c|c|c|}
\hline \multirow{2}{*}{ No } & \multirow{2}{*}{ Academic Year } & \multicolumn{4}{|c|}{ Absorption Rate } \\
\cline { 3 - 6 } & & Education units & City / Town & Province & National \\
\hline 1 & $2017 / 2018$ & 35.33 & 35.71 & 39.44 & 48.15 \\
\hline 2 & $2018 / 2019$ & 44.00 & 38.91 & 35.72 & 39.29 \\
\hline
\end{tabular}

\subsection{Data Analysis of Student Needs}

The student needs analysis data are presented in table 2 .

Table 2. The percentage of students' absorption of the digestive system material

\begin{tabular}{|c|l|c|c|}
\hline \multirow{2}{*}{ No } & & \multicolumn{1}{|c|}{ Statement } & \multicolumn{2}{c|}{ Response Options } \\
\cline { 3 - 4 } & & \multicolumn{1}{|c|}{ Yes } & No \\
\hline 2 & $\begin{array}{l}\text { The teacher often uses various methods (lectures, discussions, questions, and } \\
\text { answers) during biology lessons. }\end{array}$ & 100 & 100 \\
\hline 3 & The teacher often uses various media (PPT or video) during biology lessons & 0 & 100 \\
\hline 4 & $\begin{array}{l}\text { The teacher always conducts experiments/practicum during biology lessons, } \\
\text { especially on the material of the digestive system }\end{array}$ & 19.5 & 80.5 \\
\hline 5 & In mys always been enthusiastic during biology lessons & 92.8 & 7.2 \\
\hline 6 & $\begin{array}{l}\text { In my opinion, the material on the digestive system is one of the materials that are } \\
\text { easy to understand in biology lessons }\end{array}$ & 35.7 & 64.3 \\
\hline 7 & I have teaching materials/textbooks used by the teachers to help me understand the & 47.6 & 52.4 \\
\hline 8 & $\begin{array}{l}\text { The teaching materials used by the teacher contain language that is easy to } \\
\text { understand }\end{array}$ & 42.8 & 57.2 \\
\hline 9 & $\begin{array}{l}\text { I need other teaching materials, for example, an electronic module which material is } \\
\text { related to everyday life so that it helps to understand the concept of the digestive } \\
\text { system }\end{array}$ & 88 & 12 \\
\hline
\end{tabular}

\subsection{Data Analysis of the Needs of Biology Teachers}

Data analysis of Biology teacher needs is presented in table 3 .

Table 3. Results of the analysis of the needs of biology teachers on e-module development

\begin{tabular}{|c|c|c|}
\hline No & Question & Teacher response \\
\hline 1 & $\begin{array}{l}\text { In the learning process, what models and methods } \\
\text { do you usually use, especially to teach the concept }\end{array}$ & $\begin{array}{l}\text { In the learning process, several methods have been } \\
\text { used, such as lectures, discussions, and questions }\end{array}$ \\
\hline
\end{tabular}




\begin{tabular}{|c|c|c|}
\hline No & Question & Teacher response \\
\hline & $\begin{array}{l}\text { of the digestive system and why do you use these } \\
\text { models and methods? }\end{array}$ & $\begin{array}{l}\text { and answers. This is because this method is the most } \\
\text { widely used, easy to understand, and following } \\
\text { students' abilities. }\end{array}$ \\
\hline 2 & $\begin{array}{l}\text { Have you ever heard of the Problem Based } \\
\text { Learning (PBL) model? If so, have you applied this } \\
\text { learning model? }\end{array}$ & $\begin{array}{l}\text { I have heard of the Problem Based Learning (PBL) } \\
\text { model but never applied it to the learning process. }\end{array}$ \\
\hline 3 & $\begin{array}{l}\text { Do you often use media in learning? If so, please } \\
\text { include the type of media used }\end{array}$ & $\begin{array}{l}\text { In the learning process occasionally using learning } \\
\text { media such as charts/pictures and torso }\end{array}$ \\
\hline 4 & $\begin{array}{l}\text { Do you always do practicum/experiment activities } \\
\text { during Biology lessons, especially in the concept of } \\
\text { the digestive system? }\end{array}$ & $\begin{array}{l}\text { In the learning process, practicum/experiment } \\
\text { activities are rarely carried out. This is due to the } \\
\text { limited tools and materials for carrying out practicum } \\
\text { activities. Besides that, time constraints are also an } \\
\text { obstacle in conducting experiments }\end{array}$ \\
\hline 5 & $\begin{array}{l}\text { Have you ever heard/known about virtual } \\
\text { laboratory? If so, have you ever applied a virtual } \\
\text { laboratory in learning? }\end{array}$ & Never heard of a virtual laboratory \\
\hline 6 & $\begin{array}{l}\text { Have you encountered any obstacles in teaching } \\
\text { the concept of the digestive system? }\end{array}$ & $\begin{array}{l}\text { There are obstacles in teaching the concept of the } \\
\text { food digestive system such as the lack of students' } \\
\text { initiatives and curiosity and supporting facilities such } \\
\text { as tools and materials for conducting experiments. }\end{array}$ \\
\hline 7 & $\begin{array}{l}\text { In the learning process, what types of teaching } \\
\text { materials are used by you and whether the } \\
\text { teaching materials have used a particular learning } \\
\text { model syntax }\end{array}$ & $\begin{array}{l}\text { Teaching materials used in the learning process are } \\
\text { textbooks from several publishers. The textbook } \\
\text { used only describes the material and has not used a } \\
\text { specific learning model syntax }\end{array}$ \\
\hline 8 & $\begin{array}{l}\text { Do you have alternative teaching materials, for } \\
\text { example, a module that you made yourself, } \\
\text { especially to teach the concept of the digestive } \\
\text { system? }\end{array}$ & $\begin{array}{l}\text { In the learning process only use textbooks from } \\
\text { publishers and have never made my modules. }\end{array}$ \\
\hline 9 & $\begin{array}{l}\text { Do you need a learning module that can help } \\
\text { teach the concept of the digestive system, for } \\
\text { example, an e-module based on PBL with the help } \\
\text { of a virtual laboratory? }\end{array}$ & $\begin{array}{l}\text { Yes, there needs to be innovation in module } \\
\text { development to help to teach the concept of the } \\
\text { digestive system. }\end{array}$ \\
\hline 10 & $\begin{array}{l}\text { Has the school facilitated students with computers } \\
\text { and internet networks to support the learning } \\
\text { process? }\end{array}$ & $\begin{array}{l}\text { The school has prepared a computer that is usually } \\
\text { used for ICT lessons and fairly smooth internet } \\
\text { networks. }\end{array}$ \\
\hline
\end{tabular}

\section{DISCUSSION}

The results of the National Examination analysis according to BSNP showed that the percentage of students' absorption of the digestive system material at Baleriwu Danga Senior High School, Flores, NTT was still relatively low. Table 1 shows the percentage of students' absorption of the material during the last two years. In the 2017/2018 school year, it is known that the percentage of student absorption at the education unit, city/district, provincial, and national levels are respectively $35.73,35.71,39.44$, and 48.15 . In the 
2018/2019 academic year, it was found that the percentage of student absorption was 44.00, 38, 91, 35, 72 , and 39.29 respectively. The low absorption of materials shows that the percentage of students who answered correctly on the National Examination Test questions, especially on the digestive system material is still relatively low. In consequence, teachers as educators are required to be able to improve the quality of learning. Several aspects that need to be considered by teachers to improve the quality of learning include models, methods, media, and teaching materials used during the learning process. Therefore, it is necessary to analyze all aspects that affect the quality of learning.

Based on the result of the interview, it is known that the teacher has used several methods during the learning process such as lectures, discussions, and questions and answers. However, in general, an innovative learning model had not yet used. This is contrary to the 2013 curriculum that has been implemented in schools, where teachers are advised to use a learning model that is following the scientific approach. Problem Based Learning (PBL) is one of the models suggested in the 2013 Curriculum. PBL is a student-centered learning model [13] [14] [15] and challenges students with ill-structured problems as a stimulus to increase student motivation in the learning process [14] [16]. Ill-structured problems are complex problems, so they cannot be solved with one solution, but require students to find alternative solutions by providing reasoned arguments to support these solutions [17]. Besides that, ill-structured problems can train students to face real-world challenges in the future [18]. In PBL, problems related to everyday life are used to motivate students to identify and research concepts that need to be known to solve problems and problem-solving are the goals of PBL [19]. PBL facilitates students to work collaboratively in solving authentic problems so that they can empower critical thinking skills, communication, conceptual understanding, and knowledge across disciplines [20]. However, based on the result of the interview, it was found that the teacher had heard of the PBL model but had never implemented it.

Science learning is closely related to laboratory activities such as experiments. Experiments are an important part of science lessons, where experiments can help students understand concepts more easily and allow students to acquire skills through direct experience [21]. Besides that, experiments also allow students to gain a deeper understanding and support learning in the scientific field [22]. Based on the results of the questionnaire analysis and interview with the biology teacher, it is known that there is a gap between ideal conditions and facts in the field. The result of the questionnaire analysis showed that $100 \%$ of students stated that the teacher rarely conducts any experimental activities, especially on the digestive system material. This is in line with the results of interviews with teachers that in the learning process they rarely conduct experiments due to limited tools and materials available.

According to Özdener in [23], phenomena that cannot be investigated directly due to inadequate laboratory facilities can be overcome by using virtual laboratory media. Based on the result of the interview, it is known that the teacher has never made use of a virtual laboratory. This shows that teachers have not made full use of Information and Technology (IT) facilities such as computers and internet networks that have been provided by schools. With the available facilities, teachers can utilize virtual laboratory to continue conducting experiments. It is supported by the existence of a virtual laboratory service that can be accessed for free via the internet and can be accessed from computers or smartphones. One of the virtual laboratories that can be accessed via the internet is the PhET simulation.

Teaching materials consist of several types such as modules, textbooks, and worksheets. Based on the result of the interview, it is known that the teaching materials used by the teacher are textbooks from several publishers that are still conventional (printed). The textbook more describes the material than the activities that can help students to build up their knowledge, and from the results of the questionnaire analysis, it is known that $57.2 \%$ of students find it difficult to understand the language used in the textbook. That way, students will feel bored taking biology lessons. This is in line with the results of the questionnaire analysis and interviews with the teacher. The results of the questionnaire analysis showed that $80.5 \%$ of students were not enthusiastic during biology lessons, and from the results of the interviews it was known that the teacher had problems in teaching the concept of the digestive system, where the students desire to find out was very low. Besides that, textbooks that more describe the material than the activities that can help students build their knowledge will require students to memorize the material. This is proven by the results of the questionnaire analysis, where $92.8 \%$ of students stated biology as a memorization lesson, and $64.3 \%$ of students found it difficult to understand the concept of the digestive system. The difficulty of students understanding the concept is because students learn by memorizing which is only temporary. Besides that, from the result of the interview, it was known that the media used by the teacher in the learning process was still conventional, such as pictures or torso, and 
from the result of the questionnaire analysis, it is known that $100 \%$ of students stated that teachers had never used technology-based learning media (video or PPT). Based on the results of interviews and questionnaire analysis, it can be concluded that the learning tools used by teachers such as teaching materials and media are still conventional and this is contrary to the era of globalization which is identical with technological development.

The problems that occur need to be resolved, one of which is by developing an e-module that can meet the needs of students and teachers. E-module that can be developed are e-module based on PBL with the help of a virtual laboratory. In the PBL model, there is an investigation stage that can be carried out with an experimental method using virtual laboratory media as an alternative to overcome the limitations of laboratory facilities. The e-module development is also supported by the results of interviews with biology teachers and questionnaire analysis. The result of the interview stated that the teacher agreed to the development of a PBL-based e-module with the help of a virtual laboratory that could help the teacher to teach the concept of the digestive system and the results of the questionnaire analysis showed that $88 \%$ of students needed alternative teaching materials such as modules and $83.3 \%$ of students agreed to the development of an e-module that is interesting and can help students understand the concept of the digestive system.

Development e-module based on PBL with the help of a virtual laboratory is designed to be operated specifically via smartphones. This is supported by research by the Boston Consulting Group (BCG) and Barkley in [4] which stated that students in the global era prefer to read online using smartphones rather than reading conventionally. Besides that, smartphones can also be used to achieve various learning objectives, provide individual learning experiences [24], and are one of the more popular information technologies among students and almost all students have smartphones. That way, teachers and students can access the e-module whenever and wherever they are.

\section{CONCLUSION}

Based on the results of the needs analysis, it can be concluded that there is a need for alternative teaching materials following the development of science and technology (IPTEK) in the material of the digestive system. Thus, research can be carried out to develop alternative teaching materials, namely the development of an e-module based on PBL with the help of a virtual laboratory on digestive system material.

\section{ACKNOWLEDGMENTS}

We would like to thank the biology teacher and students of SMAK Baleriwu Danga, Flores, NTT who were willing to be part of this research, as well as all those who have helped the researchers during the process of conducting this research.

\section{REFERENCES}

[1] A. Permanasari, Kurikulum 2013: Implikasi dalam pembelajarn di sekolah, pendidikan profesi dan pendidikan tinggi, In: Prosiding Seminar Nasional Pendidikan Karakter, Vol. 01, Universitas Cokroaminoto Palopo, Palopo, 2014, Pp. 6-16.

[2] Shafa, Karakteristik Proses Pembelajaran Kurikulum 2013, Jurnal Dinamika Ilmu 14(1) (2014) 81-96. Doi: Https://Doi.Org/10.1061/(Asce)07339410(1991)117

[3] E. Ismanto, M. Novalia, P.B. Herlandy, Pemanfaatan Smartphone Android Sebagai Media Pembelajaran bagi Guru SMA Negeri 2 Kota Pekanbaru, Jurnal Pengabdian Untukmu Negeri 1(1) (2017) 42-47. Doi: Https://Doi.Org/10.37859/Jpumri.V1i1.33

[4] R.R. Saputra, A. Razak, Problem Analysis and Requirement of Biology Materials by E-Module Based on Android in SMAN 3 Padang, International Journals Of Sciences And High Technologies 20(1) (2020) 102-108.

[5] E. Cindy, S. Hmelo, Problem-Based Learning: What And How Do Students Learn?, Educational Psychology Review 16(3) (2004) 235-266. Doi: Https://Doi.Org/10.1061/(Asce)07339410(1991)117

[6] W. Hung, Problem-based learning: a learning environment for enhancing learning transfer, educational resources information center, In: J.M. Ross-Gordon, J.E. Coryell (Eds.), New Directions for Adult \& Continuing Education, Wiley Online Library, Hoboken, New Jersey, 2013, Pp. 27-38. Doi: Https://Doi.Org/10.1002/Ace.20042

[7] A. Richard, Learning To Teach, The Mc Graw Hill Education, 2013. 
[8] A.H. Salim, S. Santosa, U. Fatmawati, Penerapan Problem Based Learning (PBL) untuk Meningkatkan Kemampuan Berpikir Kritis Siswa Kelas X MIPA 2 SMA Negeri 6 Surakarta Tahun Pelajaran 2014 / 2015, Bio-Pedagogi: Jurnal Pembelajaran Biologi 4(2) (2014) 39-43.

[9] M. Wegener, T.J. Mcintyre, D. Mcgrath, C.M. Savage, M. Williamson, Developing A Virtual Physics World, Australasians Journal Of Education Technology 28(3) (2012) 504-521. Doi: Https://Doi.Org/10.14742/Ajet.847a

[10]R.K. Scheckler, Virtual Labs: A Substitute for Traditional Labs?, International Journal Of Development Biology 47(2) (2003) 231-236. Doi: Https://Doi.Org/10.1387/Ijdb.127056751

[11] L.K. Smetana, R.L. Bell, Computer Simulations to Support Science Instruction and Learning: A Critical Review of The Literature, International Journal Of Sciences Education 34(9) (2012) 1337-1370.

Doi: Https://Doi.Org/10.1080/09500693.2011.605182

[12]G. Makransky, M.W. Thisgaard, H. Gadegaard, Virtual Simulations as Preparation for Lab Exercise: Assessing Learning of Key Laboratory Skills in Microbiology and Improvement of Essential Non-Cognitive Skills, Plos One 11(6) (2016) 1-11. Doi: Https://Doi.Org/10.1371/Journal.Pone.0155895

[13] J. Savery, Overview of Problem-Based Learning: Definition and Distinction Interdisciplinary, The Interdisciplinary Journal Of Problem-Based Learning 1(1) (2006) 9-20. Doi: Https://Doi.Org/10.7771/1541-5015.1002

[14]O.S. Tan, Problem-Based Learning Pedagogies: Psychological Processes and Enhancement af Intelligences, Educational Research for Policy and Practice 6(2) (2007) 101-114. Doi: Https://Doi.Org/10.1007/S10671-007-9014-1

[15]S. Zhang, J. Xu, H. Wang, D. Zhang, Q. Zhang, And L. Zou, Effects of Problem-Based Learning in Chinese Radiology Education, Medicine 97(9) (2018) 1-6. Doi: Https://Doi.Org/10.1097/Md.000000000001006 $\underline{9}$
[16] R.M. Tamblyn, S. Barrows, Problem-Based Learning: An Approach to Medical Education, American Journal of Occupational Therapy 35(8) (1981) 539.5 Doi: Https://Doi.Org/10.5014/Ajot.35.8.539b

[17] M.Y.C.A. Kek, H. Huijser, The Power of Problem-Based Learning in Developing Critical Thinking Skills: Preparing Students for Tomorrow's Digital Futures in Today's Classrooms, Higher Education Research Development 30(3) (2011) 329-341. Doi: Https://Doi.Org/10.1080/07294360.2010.501074

[18] C. Chin, P. Lebar, M. Girls, Problem-Based Learning: Using Ill-Structured Problems in Biology Project Work, Science Education 90(1) (2005) 46-67. Doi: Https://Doi.Org/10.1002/Sce.20097

[19]B.J. Duch, D.E. Allen, S.E. Groh, The Power of Problem-Based Learning in Teaching Introductory Science Courses, Stylus Publishing, 2001.

[20] S. Wilder, Impact of Problem-Based Learning on Academic Achievement in High School: A Systematic Review, Educational Review 67(4) (2015) 414-435. Doi: Https://Doi.Org/10.1080/00131911.2014.974511

[21]Z.C.Z.T. De Jong, M.C.Linn, Physical and Virtual Laboratories in Science and Engineering Education, Science 340 (6130) (2013) 305-308. Doi: Https://Doi.Org/10.1126/Science.1230579

[22]A. Hofstein, V.N. Lunetta, The Laboratory in Science Education: Foundations for The TwentyFirst Century, Science Education 88(1) (2003) 28-54. Doi: Https://Doi.Org/10.1002/Sce.10106

[23]Ö. Karagöz, N. Özdener, Evaluation of The Usability of Different Virtual Lab Software Used in Physycs Courses, Bulgarian Journal of Science \& Education Policy 4(2) (2010) 216-235.

[24] S. Teri, A. Acai, D. Griffith, Q. Mahmoud, D.W.L. Ma, G. Newton, Student Use and Pedagogical Impact of A Mobile Learning Application, Biochemistry and Molecular Biology Education 42(2) (2014) 121-135. DOI: https://doi.org/10.1002/bmb.20771 